\title{
Impact of Chrysanthemum fontanesii extract on sodium valproate mediated oxidative damage in mice kidney
}

\author{
Amel Amrani ${ }^{12^{*}}$, Ouahiba Benaissa ${ }^{1}$, Nassima Boubekri ${ }^{1,2}$, Kenza Biod $^{2}$, Radja Djabari $^{2}$, Nawal Beroal $^{2}$, Djamila \\ Zama $^{1,2}$, Fadila Benayache ${ }^{1}$, Samir Benayache ${ }^{1}$ \\ ${ }^{1}$ Unité de Recherche Valorisation des Ressources Naturelles, Molécules Bioactives, Analyses Physicochimiques et Biologiques (VARENBIOMOL), \\ Université frères Mentouri Constantine, Route de Aïn El Bey, 25000 Constantine, Algérie. ${ }^{2}$ Departement de Biologie Animale; Faculté des SNV. Université \\ frères Mentouri Constantine, Route de Aïn El Bey, 25000 Constantine, Algérie.
}

\begin{tabular}{l} 
ARTICLE INFO \\
\hline Article history: \\
Received on: $04 / 09 / 2015$ \\
Revised on: $11 / 11 / 2015$ \\
Accepted on: $05 / 02 / 2016$ \\
Available online: $30 / 04 / 2016$ \\
\hline Key words: Valproic acid; \\
Chrysanthemum fontanesii; \\
kidney oxidant injury; \\
Antioxidant; Renoprotective \\
effect.
\end{tabular}

\section{INTRODUCTION}

Valproic acid (VPA) is an effective and widely used anticonvulsant, associated with metabolic adverse effects such as hepatotoxicity and nephrotoxicity (Gossrau and Graf, 1989; Raza et al., 2000; Rahman et al., 2006). Although the exact biochemical mechanisms of VPA toxicity to kidney have not been well defined, several hypothesis have been proposed. The recent hypothesis suggests an involvement of peroxidative injury in VPA induced renal tubular disorder (Raza et al., 1997); free radical scavengers like vitamin E supplements provided adequate protection against VPA toxicity in kidney (Aktas et al., 2010). Chrysanthemum (Asteraceae) is a large genus of about 300 species (Kumar et al., 2005) from which Chrysanthemum fontanesii growing in algeria. A series of studies have demonstrated that Chrysanthemum species possesses antioxidants (Duh et al., 1999; Lin et al., 2010; Liu et al., 2012; Amrani et al., $2013^{\mathrm{a}}$ ), anticancer (Bi et al., 2008; Jin et al., 2009), antimicrobial

\footnotetext{
* Corresponding Author

Email:amrani.a@umc.edu.dz
}

(Shunying et al., 2005), anti-inflammatory (Lee et al., 2009; Kim et al., 2012), immunomodulatory (Cheng et al., 2005), Hepatoprotective (Amrani et al., 2013 ${ }^{\mathrm{b}}$ ) and neuroprotective effects (Chun et al., 2008).Many chemical compounds have been isolated and identified from species of the Chrysanthemum (Benaissa et al., 2011, Lograda et al., 2013). Based on these effects this study was designed to determine the possible protective effect of the $n$-butanol extract obtained from flowers of Chrysanthemum fontanesii against oxidative damage of kidneys induced by VPA.

\section{MATERIAL AND METHODS}

Plants

Chrysanthemum fontanesii which is endemic to North Africa was collected during the flowering stage in the area of bijaia, north east of Algeria. Flowers (1516 g) were powdered and macerated at room temp with $\mathrm{EtOH}-\mathrm{H}_{2} \mathrm{O}(8: 2 \mathrm{v} / \mathrm{v})$ for $48 \mathrm{~h}$ three times. The filtrates were combined, concentrated and successively extracted with chloroform, ethyl acetate and $n$-butanol. The organic layers were dried with $\mathrm{Na}_{2} \mathrm{SO}_{4}$. Removal of solvents under reduced pressure, $\mathrm{CHCl}_{3}$ (7.20 g), EtOAc (30.50 g), n-butanol $(59.10 \mathrm{~g})$ resulted in final extracts (Benaissa et al., 2011). 


\section{Animals and treatment}

Female Albino Swiss mice aging from 6-8 weeks were purchased from Pasteur Institut Algiers and were maintained on $12 \mathrm{~h}$ light/dark cycle. The animals were kept in $12 \mathrm{~h}$ light/ dark cycles, maintained in an air-conditioned room at $22-25{ }^{\circ} \mathrm{C}$, with free access to food and water ad libitum. The general guidelines for the use and care of living animals in scientific investigations were followed (Council of European Communities, 1986).

Mice were divided in to five groups $(\mathrm{Gr})$ consisting of 8 animals each. All substances were given for 12 days.

1-Gr.1 served as control.

2-Gr.2 received VPA intraperitoneally (ip) at single dose of $300 \mathrm{mg} / \mathrm{kg}$ body weight for 12 days.

$3-\mathrm{Gr} .3$ received plant extract $(100 \mathrm{mg} / \mathrm{kg}$ by gavage $)$.

4-Gr.4 received plant extract $(100 \mathrm{mg} / \mathrm{kg})$ prior to VPA administration.

5-Gr.5 received vitamin $\mathrm{E}$ orally $(100 \mathrm{mg} / \mathrm{kg})$ prior to VPA administration.

After 12 days of study, all mice (eight animals in each of five groups) were killed. Kidneys were removed, weighed, and homogenized in $5 \mathrm{ml}$ of ice-cold $\mathrm{KCl} 1.15 \%$. Homogenates $(10 \%)$ were centrifuged at $3000 \mathrm{rpm}$ for $15 \mathrm{~min}$ at $4^{\circ} \mathrm{C}$, and the supernatant was kept on ice until assayed.

\section{Determination of kidney lipid peroxidation}

Lipid peroxidation, an indicator of tissue injury induced by reactive oxygen species will be measured as thiobarbituric acid reactive substance (TBARS). The amount of kidney TBARS will be measured by the thiobarbituric acid assay (TBA) as previously described by (Uchiyama and Mihara, 1978). Briefly, $0.5 \mathrm{ml}$ of kidney homogenate will be reacted with $1 \mathrm{ml}$ of TBA reagent containing $0.67 \%$ TBA and $3 \mathrm{ml}$ of $1 \%$ phosphoric acid. Samples will be boiled for 45 minutes, cooled and centrifuged. Absorbance of the supernatants will be spectrophotometrically measured at 532 $\mathrm{nm}$. TBARS concentrations will be calculated by the use of 1,3,3,3 tetra-ethoxypropane as a standard. The results will be expressed as $\mathrm{nmol} / \mathrm{g}$ tissue weight.

\section{Measurement of glutathione}

Reduced glutathione (GSH) content in the kidney was measured according to the method described by (Ellman, 1959) using Ellman's reagent. This method is based on the reactive cleavage of 5, 5'-dithiobis-(2-nitrobenzoic acid) by sulfohydryl group to yield a yellow colour with maximum absorbance at 412 $\mathrm{nm}$ against reagent blank with no homogenate.

\section{Evaluation of GPx activity}

GPx activity in the kidney was measured according to the method described by (Flohe and Gunzler, 1984). Based on $\mathrm{H}_{2} \mathrm{O}_{2}$ reduction in the medium by GPx in the presence of GSH. Briefly $0.2 \mathrm{ml}$ supernatant obtained from kidneys, $0.4 \mathrm{ml} \mathrm{GSH}(0.1 \mathrm{mM})$, $0.2 \mathrm{ml}$ TBS solution (Tris $50 \mathrm{mM}, \mathrm{NaCl} 150 \mathrm{mM} \mathrm{PH} 7.4$ ) were added to the tubes and mixed. After 5 min incubation at $25{ }^{\circ} \mathrm{C}, 0.2$ $\mathrm{ml}$ of $\mathrm{H}_{2} \mathrm{O}_{2}(1.3 \mathrm{mM})$ was added in the mixture. The reaction was stopped after $10 \mathrm{~min}$ by addition of $1 \mathrm{ml}$ trichloroacetic acid (TCA $1 \%, \mathrm{w} / \mathrm{v})$, and then the tubes maintained at $0-5^{\circ} \mathrm{C}$ in an ice bath for $30 \mathrm{~min}$, centrifuged for $10 \mathrm{~min}$ at $3000 \mathrm{rpm}$. After this, $0.48 \mathrm{ml}$ supernatant was taken and added to each tube, and then $2.2 \mathrm{ml}$ TBS solution and $0.32 \mathrm{ml}$ DTNB $(1 \mathrm{mM})$ were added. The optical density was measured at $412 \mathrm{~nm}$ in the spectrophotometer after 5 $\min$.

\section{Evaluation of catalase activity}

The enzymatic activity of catalase was measured by determining the decomposition of its substrate $\mathrm{H}_{2} \mathrm{O}_{2}$ as described by(Claiborne,1985).The homogenate was centrifuged at 10000 rpm for $45 \mathrm{~min}$ at $4^{\circ} \mathrm{C}$; the final supernatant is the source used for the evaluation of the activity of catalase. The disappearance of $\mathrm{H}_{2} \mathrm{O}_{2}$ was determined spectrophotometrically at $240 \mathrm{~nm}$. Catalase activity was expressed as U/mg of protein,

In order to express the antioxidant enzyme (GPx, catalase) activities per gram of protein, total protein concentration was determined colorimetrically by using the method of(Lowry, 1951).

\section{Histopathological examination}

Kidney tissue fragments were taken and fixed in formalin $10 \%$. The fixed specimens were then trimmed, washed and dehydrated. These specimens were then embedded in paraffin, cut into $5 \mu \mathrm{m}$ thick sections and stained with Harris hematoxylin and eosin and examined microscopically.

\section{Statistical analysis}

Data are expressed as the mean \pm SD. Statistical interferences were based on student's t-test for mean values comparing control and treated animals.

\section{RESULTS}

Effect of VPA, plant extract and vitamin $E$ on LPO, GSH levels and GPx activityin mice kidney

Treated mice with VPA have developed kidney damage as was evident from the significant increase $(\mathrm{P}<0.01)$ of LPO, which is reversed in animals treated with both $C f$ and vitamin $\mathrm{E}$ (Fig.1). VPA were significantly decline in the activities of $\operatorname{GPx}(\mathrm{P}<0.01)$, catalase and GSH level $(\mathrm{P}<0.001)$. The treatment with $C f /$ or Vit $\mathrm{E}$ showed significant improvement in the antioxidant elements (Fig. 2, 3, 4).

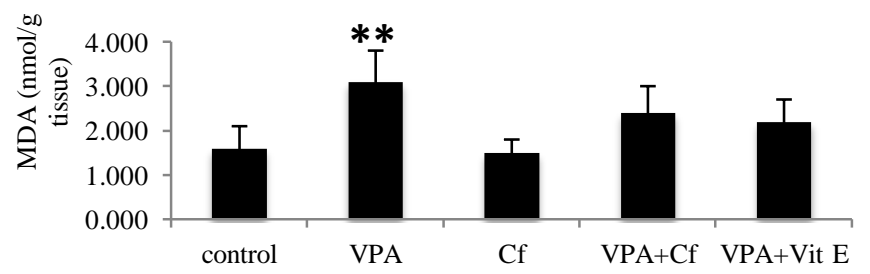

Fig. 1: Effect of VPA, plant extract and vitamin $E$ on lipid peroxidation (TBARs content) in kidney Data are reported as means \pm SD. Treatment groups were statistically compared to control group. (Students t-test, $* * \mathrm{P}<0.01$ ) 


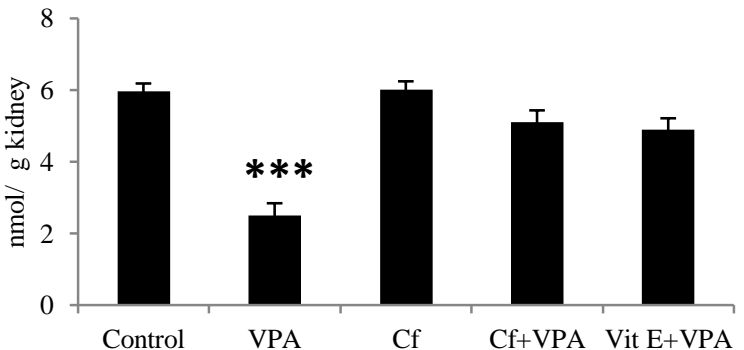

Fig. 2: Effect of VPA, plant extract and vitamin E on GSH levels in mice kidney after. 12 days of treatment. Data are reported as means \pm SD.Treatment groups were statistically compared to control group(Students t-test, $* * * \mathrm{P}<0.001)$

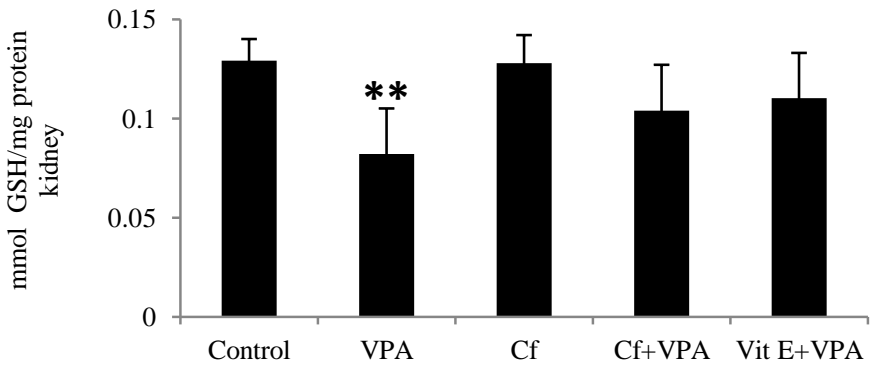

Fig. 3: Effect of VPA, plant extract and vitamin $E$ on the antioxidant enzyme (GPx). activitiesin mice kidney after 12 days treatment. Data are reported as means \pm SD., Treatment groups were statistically compared to control group. (Students t-test, $* * \mathrm{P}<0.01$ ).

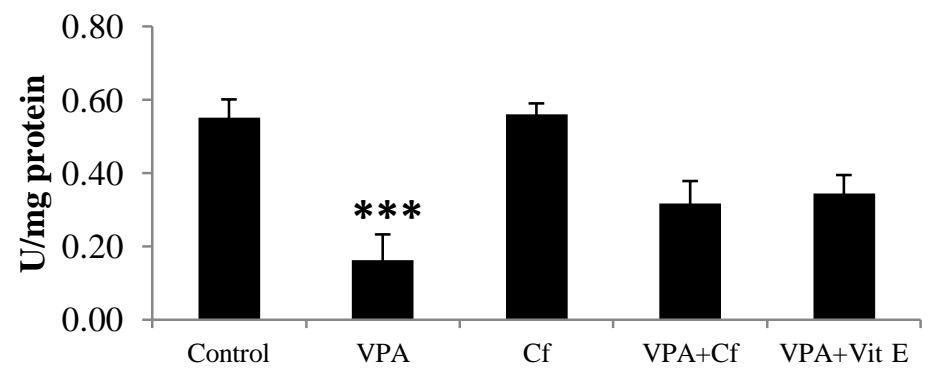

Fig. 4: Effect of VPA, plant extract and vitamin $E$ on the antioxidant enzyme (Catalase) activities in mice kidney after 12 days treatment. Data are reported as means \pm SD. Treatment groups were statistically compared to control group. (Students t-test, $* * * P<0.001$ ). Fig. 1, 2, 3 and 4: Control; VPA, treated with 300 $\mathrm{mg} / \mathrm{kg}$ valproic acid; VPA + Cf, treated with $300 \mathrm{mg} / \mathrm{kg}$ valproic acid and plant extract of Chrysanthemum fontanesii $100 \mathrm{mg} / \mathrm{kg}$; VPA+Vit E, treated with 300 $\mathrm{mg} / \mathrm{kg}$ valproic acid and $100 \mathrm{mg} / \mathrm{kg}$ vitamin E; VPA intraperitoneal injection. Plant extract and vitamin E were given by gavage. *: Significant p<0.05, **: Highly significant $\mathrm{p}<0.01 * * *$ : Very highly significant $\mathrm{p}<0.001$.

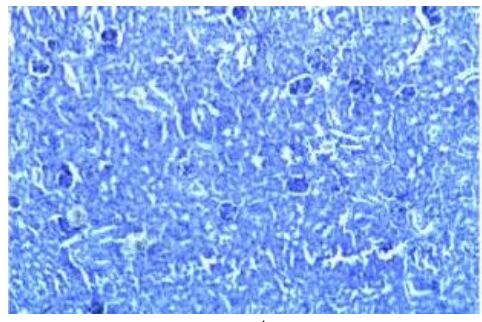

A

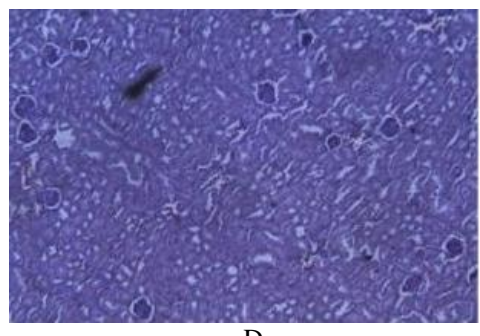

$\mathrm{D}$

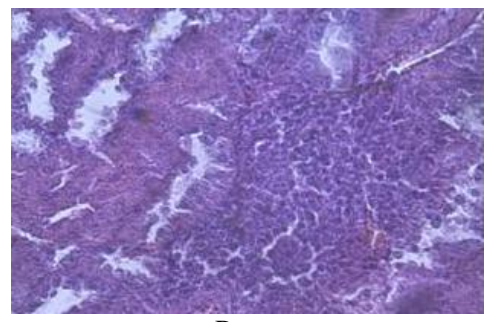

B

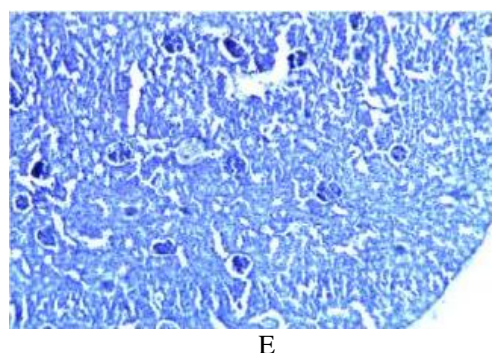

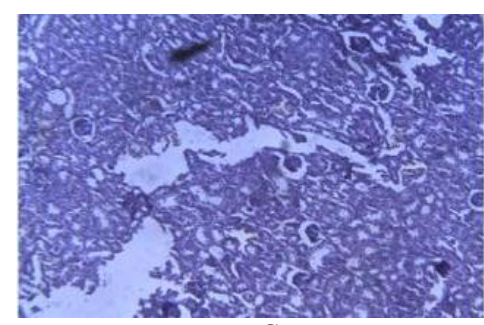

C

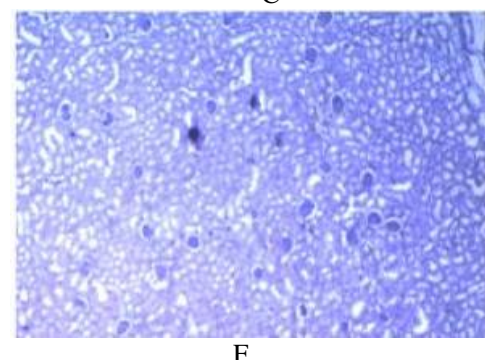

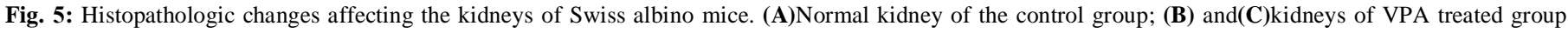
showed necrosis, inflammatory cell infiltrates and oedema respectively; (D)kidney of $C f$ group showed a histopathological picture that closely approximate that of the control group; (E) and (F)kidneys of VPA+ Vitamin E and VPA+ Plant extract treated groups respectively showed congestion.

\section{Histopathological examination}

In the slides of kidney sections of the control group stained with Hematoxylene-Eosine, the appearance of the kidney was histologically normal (figure 5A). In kidney sections of valproic acid group; necrotic areas, inflammatory cell infiltrates, oedema and congestion were observed (fig. 5 B, C). The kidney section of plant extract treated mice, showed a histopathological picture that closely approximate that of the control group(figure 5D). In the groups of VPA+ Vitamin E and butanolic extract +VPA, sections belonging to these groups showed relatively normal ultra-structure when compared to VPA group. We noted some minor changes like Congestion (figure $5 \mathrm{E}, \mathrm{F}$ ). 


\section{DISCUSSION}

Results of the present study show that catalase, GPx activities and GSH level were significantly decreased in the VPA treated mice. Several studies have reported that reactive oxygen species (ROS) are considered to be important mediators of VPA induced kidney injury (Raza et al, 1997). The increased production of ROS causes inactivation of antioxidant enzymes. Normally GSH contributed to the intracellular antioxidant defense system as it is powerful consumer of free radicals. Glutathione (GSH) is one of the most abundant tripeptide, non-enzymatic biological antioxidant present in tissues. It removes free radical species such as hydrogen peroxide, superoxide radicals and maintains membrane protein thiols. Also it is a substrate for glutathione peroxidase $(\mathrm{GPx})$ and detoxifies foreign compounds and biotransformation drugs.

CAT widely distributed in all animal tissues which decomposes hydrogen peroxide and protects the tissues from highly reactive hydroxyl radicals (Mates and Sanddiez-jimenez, 1999). Therefore, reduction in the activity of these enzymes may result in a number of alterations do to the accumulation of superoxide radicals and $\mathrm{H}_{2} \mathrm{O}_{2}$ (Halliwell, 1994). The suppression of MDA content and the over expression of the antioxidant enzymes in mice treated with $C f$ implies that this potential antioxidant defense is reactivated by the plant extract of $C f$ with a resulting increase in the capacity of detoxification through enhanced scavenging of free radicals and acted by up regulating endogenous antioxidant defenses.

Most of these effects are considered to be due to the presence of wide range of well defined phytochemical phenolic compounds and flavonoids which have been known to be responsible of health promoting (Benaissa et al., 2011, Amrani et al., 2013 ; 2014).

\section{CONCLUSION}

The present study revealed that the oral administration of n-butanol extract of Chrysanthemum fontanesii to valproic acid intoxicated mice exhibited significant nephroprotective effect. Hence, we suggest that Chrysanthemum fontanesii may be developed as successful chemotherapeutic agents.

\section{REFERENCES}

Aktas A, Nergiz Y, Akkus M, Nasır Y. The effects of valproic acid on renal corpuscle of pregnant rats and protective role of folic acid and vitamin E. Afr J Biotechnol, 2010; 9(34): 5605-5610.

Amrani A, Zama D, Boubekri N, Benaissa O, Meraihi Z, Benayache F, Benayache S, Bettuzzi S. The protective effect of Chrysanthemum fontanesii extract, vitamin $\mathrm{E}$ and $\mathrm{C}$ on sodium valproateinduced embryotoxicity in pregnant mice. J Med PlantsRes, 2012; 6: 3535-3544.

Amrani A, Boubekri N, Benaissa O, Zama D, Benayache F, Benayache $S^{\mathbf{a}}$. In vitro antioxidant, antibacterial and membrane stabilizing activity of plant extract from Chrysanthemum fontanesii. International journal of phytomedcine, 2013; 5(4): 493-498.
Amrani A, BenaissaO, BoubekriN, ZamaD, BenayacheF, Benayache $S^{b}$. Valproic acid induced liver toxicity and oxidative damage in pregnant mice: The protective effect of butanolic extract from flowers of Chrysanthemum fontanesii. Ann Biol Res, 2013; 4(12): 6-14.

Amrani A, BoubekriN, BenaissaO, ZamaD, BenayacheF, BenayacheS. Ethanol induced toxicity and lipid peroxidation in pregnant mice: Protective effects of butanolic extract from leaves of Chrysanthemum fontanesii, vitamin E and C. J. stress physiol. biochem, 2014; 10(2): 35-43.

Benaissa O, Bentamene A, Bicha S, Benayache F, Brouard I, Garcia VP, Leon F, Bermejo J., Benayache S. Flavonoid aglycones and sterol from Chrysanthemum fontanesii. Chem. Nat. Comp, 2011; 47 (Issue 1): $107-108$

Cheng W, Li J, You T, Hu C. Anti-inflammatory and immunomodulatory activities of the extracts from the inflorescence of Chrysanthemum indicum Linne. J Ethnopharmacol, 2005; 101:334-337.

Chun HS, Kim JM, Choi EH, Chang N. Neuroprotective effects of several korean medicinal plants traditionally used for stroke remedy. $\mathrm{J}$ Med Food, 2008; 11:246-251.

Claiborne A. Catalase activity In CRC Handbook of Methods for Oxygen Radical Research, ed. Greenwald RA, 1985; pp. 283-284.

DuhP-D, Tu Y-Y, Yen G-C. Antioxidant activity of water extract of harngjyur (Chrysanthemum morifolium Ramat).LWT-Food SciTechnol, 1999; 32(Issue 5): 269-277 1959; 82: 70-77.

Ellman GL. Plasma antioxidants. Arch. Biochem Biophyis,

Flohe L, Gunzler WA. Analysis of glutathione peroxidase, Methods Enzymol 1984; 105: 114-121.

Gossrau R, Graf R. Lesions and repair of cells of maternal mice after valproic acid treatment on day 8 pregnancy: an enzyme histochemical analysis. Acta Histochem, 1989; 86(1): 23-32.

Halliwell B. Free radicals, antioxidants, and human disease: curiosity, cause, or consequence? Lancet, 1994; 344 (8924): 721-724.

Jin SR, Zhu BD, Qin XH. The effect of Chrysanthemum indicum on SMMC7721, PC3 and HL60 cell lines. ZhongyaoYaoli Yu Linchuang, 2005; 21:39-41.

Kim Y, Han J, Sung J, Sung M, Choi Y, Jeong H-S, Lee' J Anti-inflammatory activity of Chrysanthemum zawadskii var. latilobum leaf extract through haem oxygenase-1 induction. Journal of Functional Foods, 2012; 4 (Issue 2): 474-479

Kumar A, Singh SP,Bhakuni R. S. Secondary metabolites of Chrysanthemum genus and their biological activities. Curr.Sci, 2005; 89 (9):1489-1501

Lee Y, Choi G, Yoon T, Cheon MS, Choo BK, Kim HK. Antiinflammatory activity of Chrysanthemum indicum extract in acute and chronic cutaneous inflammation. J Ethnopharmacol, 2009; 123:149-154.

Li ZF, Wang ZD, Ji YY, Zhang S, Huang C, LiJ, and Xia XM.Induction of apoptosis and cell cycle arrest in human HCC MHCC97H cells with Chrysanthemum indicum extract. World J Gastroenterol, 2009; 15(36): 4538-4546.

Lin GH, Lin L, Liang HW, Ma X, Wang JY, Wu LP, Jiang HD, Bruce IC, Xia Q.Antioxidant action of a Chrysanthemum morifolium extract protects rat brain against ischemia and reperfusion injury.J Med Food, 2010; 13(2):306-11.

Liu Q, Liu H, Yuan Z, Wei D, Ye Y.Evaluation of antioxidant activity of Chrysanthemum extracts and tea beverages by gold nanoparticles-based assay.Colloids Surf B.Biointerfaces, 2012; 92:348-52.

Lograda T, Ramdani M, Chalard P, Figueredo G, Silini H and Kenoufi M. Chemical composition, antibacterial activity and chromosome number of Algerian populations of two chrysanthemum species. J App Pharm Sci, 2013; 3 (8Suppl 1): S6-S11.

Lowry OH, Rosegrough NJ, Farr AL, Randall RJ.Protein measurement with the folin phenol reagent.J. Biol. Chem, 1951; 193: 265275.

Mates J.M, Sanddiez-jimenez F. Antioxydant enzymes and their implication in pathophysiologic processes. Front. Biosci, 1999; 4: d 339345. 
Rahman MH, Haqqie SS, McGoldrick MD.Acute hemolysis with acute renal failure in a patient with valproic acid poisoning treated with charcoal hemoperfusion. HemodialInt, 2006; 10(3):256-9.

Raza M, Al-Bekaire AM, Ageel AM, Qureshi S. Biochemical basis of sodium valproate hepatotoxicity and renal tubular, time dependence of peroxidative injury. Pharmacol Res, 1997; 35(2): 153-7.

Raza M, Al-shabanah OA, Al-bekairi AM,Qureshi S. Pathomorphological changes in mouse liver and kidney during prolonged valproate administration.Int J. Tissues React, 2000; 22(1):15-21.

Shunying Z, Yang Y, Huaidong Y, Yue Y, Guolin Z. Chemical composition and antimicrobial activity of the essential oils of Chrysanthemum indicum. J Ethnopharmacol, 2005; 96:151-158
Uchiyama M, Mihara M.Determination of malonaldehyde precurssor in tissues by thiobarbituric acid test. Anal. Biochem, 1978; 86: 271-278.

\section{How to cite this article:}

Amrani A, Benaissa O, Boubekri N, Biod K, Djebari R, Beroal N, Zama D, Benayache F, Benayache S. Impact of Chrysanthemum fontanesii extract on sodium valproate mediated oxidative damage in mice kidney. J App Pharm Sci, 2016; 6 (04): 067-071. 